\title{
PENILAIAN KEBUTUHAN PELATIHAN ONLINE TENTANG KURIKULUM 2013 BAGI GURU-GURU DI DIY
}

\author{
Estu Miyarso \\ Jurusan Kurikulum dan Teknologi Pendidikan FIP UNY \\ estu@uny.ac.id
}

\begin{abstract}
Penelitian ini bertujuan untuk: 1) mengetahui pemahaman guru di Wilayah DIY dalam mengimplementasikan Kurikulum 2013; 2) mengetahui perlunya etraining bagi guru di wilayah DIY dalam menerapkan Kurikulum 2013; 3) mengetahui model pelatihan e-training yang tepat bagi guru di DIY dalam mengimplementasikan kurikulum 2013. Jenis penelitian ini adalah penelitian deskriptif kuantitatif. Hasil penelitian ini menunjukkan bahwa; 1) Guru di wilayah DIY sudah memahami dan mampu menerapkan Kurikulum 2013 dengan baik. Pemahaman guru tentang penerapan pendekatan ilmiah dalam kurikulum 2013 termasuk dalam kategori baik. 2) Kurikulum e-training 2013 perlu diadakan dan dihadiri oleh para guru di wilayah DIY. e-training akan lebih tepat jika diterapkan untuk guru bersertifikasi di tingkat sekolah menengah pertama. 3) e-training yang akan diadakan akan lebih tepat ketika menerapkan blended learning. Evaluasi pembelajaran adalah isi materi yang harus diprioritaskan untuk disampaikan dalam pelatihan kurikulum 2013.
\end{abstract}

Kata kunci: penilaian kebutuhan, e-training kurikulum nasional 2013

\section{PENDAHULUAN}

Guru sebagai ujung tombak implementasi kurikulum 2013 dalam pembelajaran di kelas sudah seharusnya memiliki kompetensi pedagogi dan profesional sesuai standar yang ada. Namun sayang berdasarkan beberapa hasil penelitian menunjukkan bahwa belum semua guru memiliki standar pedagogi dan profesional dalam mengimplementasikan kurikulum 2013 sesuai yang diharapkan. Hasil penelitian Krissandi dan Rusmawan (2015) pada 65 guru SD di Yayasan Kanisius Cabang Jawa Tengah dan Yogyakarta menunjukkan bahwa guru masih mengalami kendala dalam mengimplementasikan kurikulum 2013. Kendala tersebut diantaranya terkait dengan pembuatan media pembelajaran, pemahaman guru, pemaduan antar muatan pelajaran pada pembelajaran tematik, dan penguasaan TIK.

Salah satu upaya untuk meningkatkan profesionalisme guru dalam mengimplementasikan kurikulum 2013 adalah melalui pendidikan dan pelatihan (diklat). Gardner (2008) menjelaskan bahwa pelatihan adalah teknik dan pengaturan yang bertujuan untuk mengembangkan kemampuan berpikir guru, memfokuskan pembelajaran dan belajar bereksperimen. Dengan demikian, pelatihan merupakan proses pembelajaran yang dapat digunakan untuk meningkatkan profesionalisme guru dalam implementasi kurikulum 2013. 
Dalam beberapa tahun terakhir ini sektor pendidikan berbagai upaya peningkatan kualitas pendidikan khususnya peningkatan profesional guru telah dilakukan. Salah satu kendala diklat konvensional bagi guru adalah tidak tersedianya forum diskusi peserta diklat secara berkelanjutan setelah mereka kembali ke sekolah masing-masing. Di sisi lain, kegiatan diklat konvensional yang dilakukan terlalu sering mengganggu aktivitas guru dalam melaksanakan kegiatan pembelajaran di kelas, karena saat mengikuti kegiatan diklat guru harus meninggalkan kegiatan pembelajaran di sekolah mereka.

E-training merupakan bentuk pelatihan berbasis WEB yang bisa diakses melalui internet, sehingga pembelajar dapat belajar secara on-line ditempat mereka masing-masing. E-training memungkinkan guru-guru mengikuti pelatihan tanpa harus secara fisik pergi ke tempat pelatihan, tidak meninggalkan tugas-tugas di sekolahnya, dapat belajar tanpa terikat waktu dan dapat belajar sesuai kecepatan. Untuk mengembangkan e-training Kurikulum 2013 sesuai dengan kebutuhan dan karakteristik guru SD di wilayah DIY perlu dilakukan need assessment terlebih dahulu, agar e-training dalam berjalan secara efektif dalam meningkatkan profesionalisme guru dalam implementasi kurikulum 2013.

\section{Kajian tentang Analisis Kebutuhan}

Analisis kebutuhan diklat (Training Need Assessment/TNA) merupakan langkah paling awal dalam aktivitas managemen pelatihan. Analisis kebutuhan latihan (AKL) berkenan dengan kegiatan pengumpulan informasi untuk mengetahui kebutuhan latihan apa yang dibutuhkan oleh pegawai dalam suatu organisasi.

Analisis Kebutuhan Latihan (AKL) terjadi bila ada kesenjangan antara pengetahuan atau keterampilan pegawai yang dimiliki dengan standard yang ditentukan/dibutuhkan. Menurut Soegiyono (2001), terjadinya kesenjangan antara penampilan kerja pegawai dengan standard yamg dibutuhkan bisa diakibatkan oleh :

1. Pegawai tidak tahu bagaimana cara mengerjakan disingkat DK (Deficiency of Knowledge)

2. Pegawai tahu bagaimana cara mengerjakan, tetapi tidak punya keterampilan praktis untuk mengerjakan, disingkat DP (Deficiency of Practice)

3. Pekerjaan yang dilakukan tidak jelas, atau pegawai malas, hal ini dinamakan Deficiency of Execution.

Permasalahan ke- 3 tentu tidak dapat dipecahkan dengan pelatihan, tetapi perlu pembinaan didalam pekerjaan, misalnya melalui peningkatan supervisi dan kepemimpinan. 


\section{Kajian tentang e-training}

E-training pada hakekatnya hampir mirip dengan e-learning dalam beberapa hal terutama terkait dengan metode penyampaian serta teknologi yang dipergunakan. Perbedaan utama dengan e-learning adalah bahwa $e$-training memiliki kerangka pembelajaran yang jauh lebih pendek yang biasanya khusus didesain untuk mencapai tujuan pembelajaran atau keterampilan tertentu. Jenis-jenis e-training yang lazim dipergunakan adalah video conferencing dan web-based training. Teknologi-teknologi tersebut telah diakui secara luas merupakan teknologi delivery of learning yang relatif baru, lebih baik, lebih murah, dan juga lebih cepat dibandingkan dengan metode-metode pembelajaran kelas (Bardach, 1997; Taylor, 2002). Keunggulan-keunggulan $e$-training telah dikenal secara luas meliputi efektif (dalam hal pembiayaan), konten yang tepat waktu, dan akses yang fleksibel (Hong, Lai, \& Holton, 2003; Lorenzetti, 2005; Rosenberg, 2001). Bouhnik and Marcus (2006) secara khusus menyatakan bahwa $e$-training memiliki empat keunggulan, yakni: (1) bebas untuk memutuskan kapan tiaptiap mata diklat akan dipelajari secara online, (2) tidak tergantung pada keterbatasan waktu, (3) bebas mengekspresikan pemikiran-pemikiran dan (4) aksesabilitas terhadap bahan-bahan materi mata diklat sangat terbuka.

Berdasarkan pada hasil penelitian Arkorful \& Abaidoo (2015: 401) terkait efektivitas e-learning, dijelaskan bahwa kelebihan-kelebihan e-learning antara lain: (1) fleksibilitas waktu dan tempat pembelajaran; (2) e-learning memotivasi peserta untuk berinteraksi dengan orang lain serta saling bertukar dan menghargai sudut pandang yang berbeda dalam forum diskusi; (3) e-learning bersifat cost-effective dari perspektif fleksibilitas dan jumlah peserta yang bisa menjangkau lebih banyak; (4) e-learning memiliki karakteristik penting yakni mempertimbangkan perbedaan individu peserta didik. Berbagai penelitian terkait pemanfaatan e-learning memberikan data empirik tentang potensi pengembangan $e$-learning

\section{Kajian tentang Kurikulum 2013}

Dari sekian banyak unsur sumber daya pendidikan, kurikulum merupakan salah satu unsur yang bisa memberikan kontribusi yang signifikan untuk mewujudkan proses berkembangnya kualitas potensi peserta didik. Jadi tidak dapat disangkal lagi bahwa kurikulum, yang dikembangkan dengan berbasis pada kompetensi sangat diperlukan sebagai instrumen untuk mengarahkan peserta didik menjadi: (1) manusia berkualitas yang mampu dan proaktif menjawab tantangan zaman yang selalu berubah; dan (2) manusia terdidik yang beriman dan bertakwa kepada Tuhan Yang Maha Esa, berakhlak mulia, sehat, berilmu, cakap, kreatif, mandiri; dan (3) warga negara yang demokratis dan bertanggung jawab. Pengembangan dan pelaksanaan kurikulum berbasis kompetensi 
merupakan salah satu strategi pembangunan pendidikan nasional sebagaimana yang diamanatkan dalam Undang-Undang Nomor 20 Tahun 2003 tentang Sistem Pendidikan Nasional.

\section{METODE}

Penelitian ini telah dilaksanakan pada tahun pertama dari rencana penelitian multi tahun. Jenis penelitian yang akan digunakan dalam penelitian ini adalah descriptive research dengan menggunakan pendekatan kuantitatif. Pengumpulan data yang akan dilakukan dalam penelitian ini terdiri dari 2 teknik yaitu pengumpulan data primer dan pengumpulan data sekunder. Teknik yang akan digunakan dalam pengumpulan data ini menggunakan angket elektronik atau angket online. Angket dilakukan secara snowball sampling melalaui jaringan relasi peneliti dan guru-guru di DIY. Data penelitian ini dijaring menggunakan angket elektronik dengan menerapkan empat skala likert mulai dari; tidak setuju (1), kurang setuju (2), setuju (3), dan sangat setuju (4). Teknik analisis data yang digunakan adalah deskriptif kuantitatif. Data dijaring menggunakan skala likert dengan skala penilaian 1 - 5 atau dari kriteria sangat kurang, kurang, cukup, baik, dan sangat baik. Data kemudian dianalisis secara statistik deskriptif persentase.

\section{HASIL PENELITIAN DAN PEMBAHASAN}

Sebaran guru sebagai responden penelitian ini relatif merata untuk semua semua jenjang kecuali PAUD yang paling sedikit jumlahnya yaitu $11 \%$. Dari sisi usia responden, sebagian besar respoden penelitian ini masih tergolong pada usia produktif. Mayoritas responden berkisar pada rentang usia antara 26-50 tahun sebanyak 93\% dan 7\% sisanya ada pada usia lebih dari 50 tahun. Data menunjukkan responden berjenis kelamin wanita sebanyak 50 orang atau $65,8 \%$ dan 26 orang atau sebanyak $34,2 \%$ pria. Berdasarkan data usia dan jenis kelamin responden tersebut cukup mewakili secara proporsional kondisi real guru-guru yang ada di wilayah DIY saat ini.

Diketahui bahwa sebanyak 25 orang guru atau 32,9\% responden lama mengajarnya antara 10-15 tahun, lama mengajar 5-10 tahun diakui oleh 23 orang guru atau 30,3\% responden, lama mengajar kurang dari 5 tahun diakui oleh 10 orang guru atau 13,2\% responden, lama mengajar 16-20 tahun diakui oleh 7 orang guru atau 9,2\% responden, sisanya mengakui bahwa mereka sudah lebih dari 16 tahun mengajar. Dari 76 orang guru sebagai responden, diketahui 44 orang atau $57,9 \%$ sudah bersertifikasi dan 32 orang atau 42,1\% menyatakan belum bersertifikasi. 


\section{Pemahaman guru-guru di wilayah DIY dalam mengimplementasikan Kurikulum 2013}

Pemahaman guru tentang kurikulum 2013 meliputi; pemahaman tentang isi buku pedoman kurikulum 2013, pemahaman tentang penerapan pendekatan saintifik, pemahaman tentang langkah-langkah pembelajaran inquiry, pemahaman tentang langkah-langkah pembelajaran berbasis proyek, dan pemahaman tentang pendekatan berbasis masalah sebagai ciri dari kurikulum 2013. Selain memahami, guru juga dituntut untuk mengimplementasikan kurikulum 2013 dalam kegiatan pembelajaran di kelas. Adapun kemampuan implementasi ini meliputi kegiatan merencanakan, melaksanakan, hingga mengevaluasi kurikulum dalam praktek pembelajaran.

Secara umum hasil penelitian ini menunjukkan bahwa guru-guru di wilayah DIY sudah memahami Kurikulum 2013 dengan baik. Hal ini diketahui dari hasil rerata penilaian pemahaman guru tentang isi buku pedoman kurikulum 2013 menunjukkan skor 2,74 atau masuk kategori baik. Rincian data tentang pemahaman responden terhadap kurikulum 2013 dapat ditunjukkan dalam tabel sebagai berikut:

Tabel 1

Rerata skor guru dalam memahami kurikulum 2013

\begin{tabular}{lccc}
\multicolumn{1}{c}{ Pemahaman guru tentang } & \multicolumn{3}{c}{ Kategori Responden } \\
\cline { 2 - 4 } & $\begin{array}{c}\text { Semua } \\
\text { guru }\end{array}$ & $\begin{array}{c}\text { Sudah } \\
\text { bersertifikasi }\end{array}$ & $\begin{array}{c}\text { Belum } \\
\text { bersertifikasi }\end{array}$ \\
\hline Isi modul Kurikulum 2013 & 2,74 & 2,8 & 2,59 \\
\hline Pendekatan pembalajaran saintifik & 2,78 & 2,78 & 2,78 \\
\hline Langkah-langkah pembelajaran inquiry & 2,64 & 2,73 & 2,53 \\
\hline Langkah pembelajaran berbasis proyek & 2,67 & 2,67 & 2,66 \\
\hline Pendekatan berbasis masalah & 2.66 & 2.67 & 2,66
\end{tabular}

Berdasarkan Tabel 1 di atas, dapat diketahui pula perbandingan rerata skor penilaian tentang pemahaman guru mengenai kurikulum 2013 untuk mereka yang sudah bersertifikasi maupun yang belum bersertifikasi. Guru yang sudah bersertifikasi terlihat lebih memahami isi modul pedoman kurikulum 2013 dengan skor rerata 2,8 atau masuk kategori baik dibanding guru yang belum bersertifikasi dengan skor rerata 2,59 atau masuk kategori kurang baik.

Berikut ini adalah tabel tentang kemampuan guru sebagai responden dalam mengimplementasikan kurikulum 2013 dalam tabel berikut: 
Tabel 2

Rerata skor kemampuan guru dalam mengimplementasikan kurikulum 2013

Kemampuan guru dalam

Kategori Responden

\begin{tabular}{lccc}
\cline { 2 - 4 } & $\begin{array}{c}\text { Semua } \\
\text { guru }\end{array}$ & $\begin{array}{c}\text { Sudah } \\
\text { bersertifikasi }\end{array}$ & $\begin{array}{c}\text { Belum } \\
\text { bersertifikasi }\end{array}$ \\
\hline Menyusun rencana pembelajaran tematik & 2,79 & 2,84 & 2,72 \\
\hline Melaksanakan kegiatan pembelajaran tematik & 2,62 & 2,71 & 2,53 \\
\hline Melaksanakan evaluasi pembelajaran tematik & 2,51 & 2,53 & 2,50
\end{tabular}

Berdasarkan Tabel 2 di atas, dapat diketahui perbandingan rerata skor penilaian tentang kemampuan guru dalam mengimplementasikan kurikulum 2013 bagi mereka yang sudah bersertifikasi maupun yang belum bersertifikasi. Secara umum, guru yang sudah bersertifikasi tampak lebih mampu dibanding guru yang belum bersertifikasi. Hal ini terlihat dari skor rerata yang diperoleh guru bersertifikasi lebih tinggi dibanding guru yang belum bersertifikasi.

Guru-guru yang sudah bersertifikasi kemampuan evaluasi pembelajarannya lebih stabil dibanding guru yang belum bersertifikasi. Semakin lama masa mengajarnya maka kemampuan evaluasi pembelajaran yang dilakukan guru bersertifikasi terlihat semakin baik. Hal ini tidak terjadi pada guru yang belum bersertifikasi. Kemampuan evaluasi pembelajaran yang dilakukannya lebih bersifat fluktuatif dan tampaknya tidak dipengaruhi oleh faktor lamanya mereka mengajar.

\section{Kebutuhan Penyelenggaraan e-training bagi Guru-guru di Wilayah DIY dalam Mengimplementasikan Kurikulum 2013}

Kebutuhan penyelenggaraan e-training ini lebih didasarkan pada urgensi dan kepentingan yang dirasakan langsung oleh guru-guru selaku responden penelitian ini sekaligus sebagai calon peserta yang akan melaksanakannya. Kebutuhan penyelenggaraan e-training ini juga dipengarui oleh faktor-faktor pendukung sebagai variabel kontrol agar e-training yang akan dilaksanakan nantinya benar-benar bisa tepat guna dan tepat sasaran. Data dua hal tersebut dapat disajikan dalan tabel berikut:

Tabel 3

Penilaian Kebutuhan e-Training Kurikulum 2013

Pemahaman guru tentang

Kategori Responden

\begin{tabular}{|c|c|c|c|}
\hline & \\
\hline & $\begin{array}{c}\text { Semua } \\
\text { guru }\end{array}$ & $\begin{array}{c}\text { Sudah } \\
\text { bersertifikasi }\end{array}$ & $\begin{array}{c}\text { Belum } \\
\text { bersertifikasi }\end{array}$ \\
\hline Urgensi e-training Kurikulum 2013 bagi guru & 3,38 & 3,47 & 3,28 \\
\hline \multicolumn{4}{|l|}{ Faktor pendukung : } \\
\hline Kemampuan mengoperasikan laptop/ PC & 3,34 & 3,24 & 3,50 \\
\hline Kemampuan aplikasi program komputer & 3,28 & 3,16 & 3,44 \\
\hline Kemampuan menghubungkan internet & 3,33 & 3,24 & 3,47 \\
\hline Kemampuan browsing dan aplikasi online & 3,24 & 3,09 & 3,47 \\
\hline Ketersediaan jaringan internet di sekolah & 2,83 & 2,80 & 2,91 \\
\hline Ketersediaan jaringan internet di rumah & 2,34 & 2,44 & 2,25 \\
\hline
\end{tabular}


Berdasarkan Tabel 3 di atas, dapat diketahui bahwa semua responden menilai bahwa etraining Kurikulum 2013 perlu atau penting untuk diselenggarakan dan diikuti oleh guru-guru di wilayah DIY. Hal yang menarik pada skor tabel tersebut yaitu bahwa guru yang sudah bersertifikasi memperoleh skor rerata lebih tinggi $(3,47)$ dibanding skor rerata $(3,28)$ guru yang belum sertifikasi. Hal ini bisa dimaknai bahwa guru yang sudah bersertifikasi nampaknya justru menganggap lebih penting perlunya e-training dibandingkan guru yang belum bersertifikasi.

\section{Gambaran model e-training bagi guru-guru di wilayah DIY dalam mengimplementasikan Kurikulum 2013 yang paling tepat.}

Penelitian yang lebih berfungsi sebagai studi pendahuluan ini tentu sangat penting dilakukan sebagai dasar pijakan dalam mengembangkan model e-training sebelum diselenggarakan. Berdasarkan temuan hasil penelitian ini pada point 1 dan 2 di atas, setidaknya sudah ada dua hal yang bisa memenuhi dimulainya desain model e-training sebagai tindak lanjut dari penelitian ini berikutnya. Dua hal tersebut yaitu 1) berkenaan dengan konten atau materi kurikulum 2013 apa yang perlu disampaikan dan 2) target/ sasaran mana yang paling tepat untuk dijadikan peserta e-training nantinya.

Berdasarkan hasil kajian dan analisis masalah tentang pemahaman dan kemampuan guru dalam mengimplementasikan kurikulum 2013, evaluasi pembelajaran adalah konten materi yang sebaiknya paling diprioritaskan untuk disampaikan. Selain itu, langkah-langkah prosedur pelaksanaan pembelajaran berbasis inquiry, berbasis masalah, berbasis proyek juga perlu mendapat prioritas selanjutnya. Demikian juga terkait dengan perencanaan pembelajaran terutama penyusunan RPS/ RPP yang sesuai dengan kurikulum 2013 perlu tetap diberikan kepada peserta meski dalam proporsi yang mungkin lebih sedikit.

Target dan sasaran e-training berdasarkan analisis kebutuhan yaitu guru-guru di wilayah DIY untuk jenjang SD/ MI berikutnya untuk jenjang PAUD, jenjang SLTP baru jenjang SLTA bagi mereka yang belum bersertifikasi. Adapun bagi guru yang sudah bersertifikasi akan lebih tepat bila diprioritaskan pada guru jenjang SLTP, berikutnya PAUD/ TK, SLTA, dan terakhir $\mathrm{SD} / \mathrm{MI}$.

Secara teknis, e-training yang akan diselengarakan ini perlu dikondisikan agar peserta atau guru masih berada di area sekolah untuk lebih mempermudah akses internet meski bisa saja diakses di mana pun. Pemilihan calon peserta yang relatif muda tentunya akan lebih mendukung secara teknis dalam penguasaan IT. Terlepas dari hal itu, karena konten yang akan disampaikan lebih banyak bersifat praktis tentu saja pelaksanaan e-training yang akan diselenggarakan tidak murni menggunakan model full online tapi lebih tepat bila menerapkan 
blainded learning atau campuran antara pertemuan tatap muka secara langsung dan on line atau daring (dalam jaringan).

\section{SIMPULAN}

Secara umum hasil penelitian ini menunjukkan bahwa guru-guru di wilayah DIY sudah memahami Kurikulum 2013 dengan baik. Adapun data tentang kemampuan guru di wilayah DIY dalam mengimplementasikan kurikulum 2013 menunjukkan trend yang kurang baik. Hal ini didasarkan pada skor rerata hasil penilaian kemampuan guru dalam melaksanakan, maupun mengevaluasi kurikulum 2013 yang menunjukkan skor 2,62 dan skor 2,51 masuk kategori kurang baik.

E-training Kurikulum 2013 perlu atau penting untuk diselenggarakan dan diikuti oleh guru-guru di wilayah DIY. Guru yang sudah bersertifikasi nampaknya justru menganggap lebih penting perlunya e-training dibandingkan guru yang belum bersertifikasi. E-training akan lebih tepat bila dilaksanakan bagi guru-guru yang telah bersertifikasi di wilayah DIY pada jenjang SLTP atau bisa juga akan lebih tepat dilaksanakan bagi guru-guru yang belum sertifikasi di wilayah DIY pada jenjang SD.

Berdasarkan analasis kebutuhan maka model pelaksanaan e-training yang akan diselenggarakan tidak murni menggunakan model full online tapi lebih tepat bila menerapkan blended learning atau campuran antara pertemuan tatap muka secara langsung dan online atau daring (dalam jaringan). Evaluasi pembelajaran adalah konten materi yang sebaiknya paling diprioritaskan untuk disampaikan. Selain itu, langkah-langkah prosedur pelaksanaan pembelajaran berbasis inquiry, berbasis masalah, berbasis proyek juga perlu mendapat prioritas selanjutnya. Demikian juga terkait dengan perencanaan pembelajaran terutama penyusunan RPS/ RPP yang sesuai dengan kurikulum 2013 perlu tetap diberikan kepada peserta meski dalam proporsi yang mungkin lebih sedikit.

\section{DAFTAR PUSTAKA}

Arkorful, V., \& Abaidoo, N.A. (2015). The Role of e-Learning, Advantages and Disadvantages of Its Adoption in Higher Education. International Journal of Instructional Technology and Distance Learning, 12(1), 29-43. Diunduh dari http://doi.org/10.3991/ijac.v3i2.1322. Diakses pada tanggal 25 Januari 2018.

Bardach, K. C. (1997). Patterns and trends in executive education. Selections, 14(1), 18-25.

Bouhnik, D., \& Marcus, T. (2006). Interaction in distance-learning courses. Journal of the American Society Information Science and Technology, 57(3), 299-305. 
Hong, K. S., Lai, K. W., \& Holton, D. (2003). Students'satisfaction and perceived learning with web-based course. Educational Technology and Society, 6(1), 116-124.

Kementerian Pendidikan dan Kebudayaan. (2012). Dokumen Kurikulum 2013. Jakarta: Kemendikbud.

Sugiyono. (2002). Manajemen Diklat. Bandung: Alfabeta. 